ЧЕХУНОВ Д. М., аспірант (Український державний університет залізничного транспорту)

\title{
Формування моделі оцінки ризиків на сортувальній станції при оперуванні вагонами 3 небезпечними вантажами із використанням математичних апаратів нечіткої логіки та байссових мереж
}

Розроблено модель очінки імовірності виникнення аварій з вагоном із небезпечним вантажем на сортувальній станиії з використанням математичного апарату байєсових мереж та нечіткої логіки. Модель при розрахунку імовірності враховує фактори, щзо відносяться до всіх класів небезпеки, і причинно-наслідкові зв'язки між подіями, щзо впливають на неї, надає можливість використовувати інформацію про подї та поточний стан об'єктів на сортувальній станції. Модель дозволяє детально очінити ризик виникнення аварій $з$ вагоном із небезпечним вантажем і побудувати функиії ненадійності від часу.

Ключові слова: вагони з небезпечними вантажами, байєсові мережі, нечітка логіка, оцінка імовірності аварії.

\begin{abstract}
Постановка проблеми
Питання розробки сучасних технологій управління транспортними процесами, які здатні мінімізувати кількість аварій під час транспортування небезпечних вантажів (НВ) та масштаби їх наслідків для суспільства та народного господарства, $€$ вкрай важливим, зокрема для України.

Важливість цього завдання обумовлена не лише наявністю великої кількості виробників та споживачів продукції, що відноситься до категорії НВ та може спричинити значну шкоду для здоров'я людей та екології у разі аварії під час ii транспортування залізницею, але також збільшенням обсягів перевезень військових вантажів в умовах проведення антитерористичної операції та підвищенням рівня терористичних загроз в Україні.
\end{abstract}

Враховуючи вищенаведене найбільшої уваги потребують об'єкти, які $\epsilon$ найважливішими на залізничній мережі, особливо з точки зору перевезень НВ. В першу чергу до таких об'єктів необхідно віднести залізничні сортувальні станції (CC). Зазвичай вони входять до складу великих залізничних вузлів, які у свою чергу розташовані у безпосередній близькості від мегаполісів або крупних населених пунктів. Сортувальні станції $є$ місцем постійної концентрації великої кількості вантажних вагонів, в тому числі й вагонів 3 НВ. Таким чином, аварії на територіях сортувальних станцій, у яких можуть бути задіяні ці вагони, можуть спричинити дуже серйозні наслідки, що пов'язані із життям та здоров'ям мешканців цих населених пунктів, кількість яких може сягати від декількох десятків тисяч до декількох мільйонів осіб,

(С) Д. М. Чехунов, 2018 штатних працівників станції, кількість яких може сягати декількох тисяч осіб. Крім того, на багатьох сортувальних станціях виконується робота 3 пасажирськими поїздами. До того ж аварії з вагонами 3 НВ можуть на тривалий час зупинити роботу всієї сортувальної станції. Наслідками такої аварії можуть стати серйозні збої у технологічному процесі цілої залізничної мережі, що не лише спричинять значні матеріальні збитки, але й у сучасних умовах можуть вплинути на обороноздатність країни і становитимуть загрозу національній безпеці.

Таким чином, актуальним $\epsilon$ питання розробки сучасної автоматизованої системи управління ризиками на сортувальних станціях. Першим етапом побудови такої системи є формування адекватної моделі оцінки ризику виникнення аварії з вагонами 3 НВ на сортувальній станції.

\footnotetext{
Аналіз останніх досліджень і публікацій

У статті [1] зазначено необхідність та запропоновано модель формування поїздів для зменшення ризику на перегонах i сортувальних станціях при транспортуванні НВ на рівні тактичного планування. При цьому залишився нерозглянутим оперативний рівень та відсутня деталізація складових ризику, не враховано складову ризику, що пов'язана 3 можливістю виникнення аварії 3 вагоном 3 причини аварії з іншим вагоном. У статті [2] розглядається задача планування маршрутів поїздів із вагонами з НВ 3 метою зниження ризику. Задачу пропонується вирішувати на тактичному рівні. При визначенні оптимальної кількості i складу маршрутів для задоволення потреби на перевезення НВ враховуються зони обслуговування та інші параметри залізничної мережі. Але питанню зниження ризику під час
} 
перебування вагонів з НВ на сортувальних станціях майже не приділено уваги. У статті [3] також вирішується задача маршрутизації вагонів 3 HВ на залізничній мережі 3 урахуванням можливості здійснення інтермодальних перевезень НВ. Питанням зниження ризику під час виконання станційних операцій приділено недостатньо уваги, незважаючи на те, що за такою технологією перевезень до станційних операцій ще додається і операція перевантаження НВ на автомобільний транспорт. У статті [4] запропоновано оригінальну модель прийняття рішень 3 метою зменшення ризику під час пропускання поїздів, що містять у своєму складі вагони 3 НВ, через сортувальні станції. Недоліком даної моделі можна вважати те, що ступінь ризику задається а не визначається моделлю.

\section{Виділення невирішених раніше частин загальної проблеми \\ Виходячи 3 аналізу останніх досліджень, невирішеними залишаються такі питання: побудова моделі оцінки ризику при оперуванні поїздами та вагонами 3 HB на сортувальних станціях, яка б надавала можливість в автоматизованому режимі використовувати всю наявну інформаційну базу (статистичні дані, оперативна інформація, прогнозна інформація) та була б здатна оцінити величину ризику для будь якого моменту часу впродовж планового періоду.}

\section{Формулювання цілей \\ Першочерговою задачею для досягнення мети щодо розробки автоматизованої технології управління ризиками на сортувальних станціях є створення моделі для кількісної оцінки небезпек та ризиків, що пов’язані з ними, шляхом урахування невирішених питань.}

\section{Викладення основного матеріалу дослідження}

Оцінка ризиків під час виконання технологічних операцій на об'єктах залізничного транспорту являє значну складність тому, що вони постійно знаходяться під впливом всіх існуючих класів небезпек: природнього, техногенного та антропогенного походження.

Для кількісної оцінки небезпек та їх можливих наслідків використовується поняття технічного ризику. Ідея використання поняття технічного ризику полягає в тому, щоб об'єднати імовірнісну оцінку настання небажаної події 3 оцінкою іiі можливих наслідків, тобто втрат у вигляді єдиного кількісного критерію. Як відомо, ризик доцільно подавати як добуток імовірності події і величини збитків у разі їі настання. Такий підхід є раціональним, але лише його недостатньо для побудови моделі оцінки ризиків складних систем, таких як підсистеми залізничної транспортної системи, зокрема сортувальної станції.

Ризики, що наявні в процесі функціонування таких підсистем, як сортувальні станції, постійно змінюються у часі і зазвичай є взаємопов'язаними між собою. Тому часовий аспект в моделі оцінки ризиків повинен відігравати важливу роль.

Розглянемо випадок, коли на сортувальній станції знаходиться лише один вагон із небезпечним вантажем. У випадковий момент часу з вагоном може статись аварія, причиною якої стане, наприклад, схід 3 рейок у результаті відмови вузла ходової частини вагона, або руйнування котла цистерни, що на основі вищенаведеної класифікації є наслідком дії небезпек, які відносяться до класу антропогенних. Таким чином, на вагон діє потік відмов, який пов'язаний із самим вагоном. Такі види відмов пов'язані в тому числі із процесами старіння та зносу, тому їх не можна вважати повністю незалежними подіями потоку, а такий потік відмов не володіє марковською властивістю, тому для визначення імовірності відмови доцільно використовувати розподіл Вейбулла. Але вагон також міг зійти з рейок у результаті зламу рейки або тяги стрілочного переводу, або відмови засобів станційної автоматики, помилки чергового по станції, маневрового диспетчера або сигналіста, ці небезпеки відносяться до класу антропогенних. Цей потік відмов пов'язаний вже не 3 вагоном, а зі станцією, але він також діє й на вагон.

На відміну від класичного підходу, побудови моделей природи випадковості людського фактора як причини аварій при управлінні складними технічними системами, доводять доцільність побудови моделей, що базуються на функціях розподілу експоненційного типу, результати сучасних досліджень яких використовують функції розподілу типу Вейбулла. Використання розподілу Вейбулла обумовлене необхідністю підвищення адекватності моделей завдяки наданню можливості подання помилки 3 причини людського фактора не лише як абсолютно незалежної випадкової події, а як випадкової події, яка замикає ланцюг випадкових подій, більшість 3 яких зазвичай $є$ латентними. До речі, потік відмов, що пов'язаний з вагоном, також містить складову, за яку є відповідальним людський фактор, тому що аварія може статися й $з$ причини помилки при навантаженні, пакуванні або закріпленні небезпечного вантажу, помилки під час огляду та виконання ремонту вагона на станції навантаження або в депо.

Таким чином, розподіл Вейбулла дозволить одночасно врахувати в єдиній моделі як відмови, що пов'язані 3 виходом 3 ладу інфраструктурних елементів, рухомого складу і технічного обладнання, так і відмови, що пов'язані з помилками оперативного персоналу залізничної станції. 
Отже, для побудови адекватної моделі оцінки ризику, що пов'язаний 3 перебуванням вагона на сортувальній станції, необхідно врахувати одночасно ці обидва потоки відмов. 3 цією метою доцільно сформувати єдину функцію, яка б одночасно враховувала ці потоки. Для цього необхідно здійснити поєднання двох розподілів Вейбулла.

Теоретично існують декілька методів оцінки параметрів розподілу, який є результатом поєднання розподілів двох незалежних випадкових величин. Але всі вони є доволі складними і мають свої недоліки. Крім того, поєднання саме розподілів Вейбулла є малодослідженим, хоча і являє значний практичний інтерес. Більшість цих досліджень стосується спрощених часткових випадків, наприклад, коли обидва розподіли мають однакову величину параметра форми тощо. Більшість 3 цих методів є чисельними, багато з чисельних методів $є$ ітераційними. Навіть такі методи, як метод моментів або метод максимальної правдоподібності хоча й вважаються аналітичними, але використовують набори точкових значень функцій щільності розподілів або кумулятивних функцій розподілів для побудови системи рівнянь. Навіть побудова моделі, яка, наприклад, являє згортку двох функцій розподілу Вейбулла, може виявитися складним процесом, який до того ж потребує виконання значних обсягів обчислень.

Виходячи $з$ вищенаведеного, для побудови функції ненадійності вагона 3 небезпечним вантажем, за допомогою якої для будь-якого моменту планового періоду можна було б отримати адекватну оцінку імовірності виникнення аварії, необхідно врахувати низку факторів, які також можна трактувати як імовірнісні змінні. Раціональний шлях вирішення цієі задачі - залучення сучасних концепцій, що покладені в основу математичного апарату байєсових мереж, які дозволять максимально повно враховувати всю наявну інформацію i подолати вищезазначені складнощі. Перевага цих методів над класичними не лише в тому, що вони використовують графові структури, які дозволяють знизити рівень математичної складності завдяки впровадженню розподілених обчислень, а також надають можливість отримати максимум користі від використання імовірності, розширюючи інтерпретацію цього поняття. Результатом реалізаціі цих концепцій $є$ виникнення нових теорій, таких як, наприклад, теорія очевидностей Демпстера-Шефера та створення нового математичного апарату, який здатен вирішувати складні задачі, долаючи обмеження класичної теорії. Математичний апарат байєсовських мереж - це сучасний математичний апарат, який являє графову імовірнісну модель, що здатна відтворювати імовірнісні зв'язки між змінними на основі байєсових імовірнісних залежностей. Ці залежності використовують поняття байєсової імовірності, яка, на відміну від класичної інтерпретації як міри можливості настання події, може використовуватись і як ступінь впевненості в істинності судження. Байєсові мережі використовують поняття апріорної i апостеріорної імовірностей, які є імовірностями до і після отримання знань про подію відповідно.

Суть теореми Байєса відображається формулою Байєса

$P(A \mid B)=\frac{P(B \mid A) P(A)}{P(B)}$

де $P(A)$ та $P(B)$ - імовірності подій $A$ та $B$ безвідносно одна до одної;

$P(A \mid B)$ - умовна імовірність, імовірність настання події $A$ за умови істинності $B$;

$P(B \mid A)$ - умовна імовірність, імовірність спостереження події $B$ за умови істинності $A$.

Застосування байєсовського підходу в моделях оцінки імовірності виникнення подій дозволяє підвищити їх точність завдяки можливості врахування додаткової інформації. Наприклад, якщо планувальник володіє інформацією про те, що певна подія відбулася (або не відбулася), або змінилася ііі імовірність, і ця подія має певний статистичний зв'язок 3 подією, імовірність якої оцінюється, тоді імовірність цієї події може бути уточнена, що може суттєво змінити результат оцінювання.

Під час побудови оперативного плану роботи сортувальної станції $\epsilon$ можливість використання додаткової інформації, яку необхідно врахувати для підвищення адекватності моделі оцінювання ризиків. Наприклад, існує імовірність виникнення аварії вагона $3 \mathrm{HB}$ не лише через проблеми із самим вагоном або технічними відмовами, що пов'язані зі станцією. Небезпека може загрожувати і з боку інших вагонів 3 $\mathrm{HB}$, які знаходяться поряд. Небезпека полягає в тому, що аварія 3 вагоном може виникнути також i 3 причини пошкодження вантажу, яке може відбутися внаслідок аварії 3 іншим вагоном 3 НВ, який знаходиться поряд. Така імовірність може бути значно вищою, ніж імовірність виникнення аварії із самим вагоном. Тому урахування цієї інформації $є$ також важливим.

Складність побудови моделі в даному випадку полягає у тому, що для включення цієї інформації у склад байєсової мережі необхідно володіти статистичними даними про взаємний вплив факторів, що утворюють такого роду небезпеки та які можна було б використати для побудови таблиць умовних ймовірностей. Але такі статистичні дані в необхідному обсязі відсутні. Крім того, більшість байєсових мереж $\epsilon$ дискретними, що пов'язане в першу чергу 3 
простотою їх побудови й виконанням обчислень. Дискретні байєсові мережі потребують дискретизації факторів, які зазвичай подаються неперервними змінними, а це в свою чергу веде до значного збільшення кількості змінних та відповідних вузлів байєсової мережі. Тобто одній неперервній змінній будуть відповідати декілька дискретних змінних, кожна з яких буде визначати, чи потрапляє значення неперервної змінної у деякий інтервал.

3 метою розширення сфери застосування байєсових мереж та збільшення їх можливостей останніми роками набувають розвитку теоретичні i практичні дослідження, що спрямовані на розширення математичного апарату байєсових мереж шляхом інтеграції до їх складу інших математичних конструкцій. Одним 3 напрямків реалізації такої інтеграції є дослідження можливості об'єднання байєсових мереж й математичного апарату нечіткої логіки. В теперішній час існують також моделі, які дозволяють оперувати імовірнісними змінними у байєсовій мережі за правилами нечіткої логіки. Також існують підходи до формування моделей на основі байєсових мереж, які не змінюють класичних принципів їх функціонування, a змінюють лише правила формування виведення окремих змінним шляхом інтеграції до їх складу моделей, що використовують інші математичні апарати. Таке різноманіття типів байєсових мереж обумовлене популярністю їх використання як основи для створення експертних систем.

Для одночасного врахування всіх класів небезпек і надання їм кількісної оцінки у вигляді імовірності виникнення аварії 3 вагоном 3 HВ пропонується сформувати модель на основі байєсової мережі, до складу якої буде інтегровано модель на основі апарату нечіткої логіки. Використання нечіткої логіки надасть можливість запобігання надмірного збільшення масштабу байєсової мережі за рахунок ефективного i компактного подання експертних знань.

Нечітка логіка застосовується у вигляді системи нечіткого виведення (англ. fuzzy inference system), яка являє собою продукційну модель знань. Вона складається із бази нечітких правил, які оперують нечіткими змінними. Нечіткі змінні складаються із наборів термів, які являють собою функції приналежності до набору нечітких множин. Функціонує така система за допомогою спеціальних математичних процедур, які здатні оперувати нечіткими числами. Існує декілька типів систем нечіткого виведення. Найбільш розповсюдженою системою $є$ система типу Мамдані, в якій використовується математична процедура, що має назву «імплікація Мамдані».

Систему типу Мамдані пропонується використати для моделювання імовірності виникнення аварії 3 вагоном з НВ, яка може відбутися внаслідок аварії 3 іншим вагоном з НВ.

Для побудови моделі оцінювання імовірності аварії з вагоном з НВ на сортувальній станції доцільно обрати архітектуру системи нечіткого виведення типу Мамдані, тому що вона $є$ інтуїтивно зрозумілою i дозволяє створювати або корегувати базу правил на основі експертних оцінок.

Процес моделювання розпочинається зі створення вихідної нечіткої моделі. Ця модель необхідна для того, щоб визначити кількість входів та кількість лінгвістичних змінних.

На імовірність пошкодження вантажу у результаті аварії $з$ іншим вагоном з НВ впливають такі фактори: ступінь небезпеки, яка визначається родом вантажу вагонів з НВ, що знаходяться поряд; відстань, на яку ці вагони віддалені; їх кількість. Ці три параметри, які безпосередньо визначають ступінь імовірності аварії, що може бути спровокована аварією $з$ іншим вагоном, подано як нечіткі змінні. Кожна така змінна має свою галузь визначення, на якій визначена нечітка підмножина термів. Кожен терм подано функцією приналежності, що визнає ступінь приналежності числового значення до закріпленого за ним значення лінгвістичної змінної, який відповідає певній властивості нечіткої змінної.

Для завершення формування нечіткої моделі було створено базу правил за методом експертних оцінок.

На рис. 1 наведено три вхідні і одна вихідна змінна сформованої нечіткої моделі оцінювання імовірності виникнення аварії з вагоном, що перевозить НВ, на сортувальній станції.

На рис. 2 наведено сформовану експертним шляхом байєсову мережу у вигляді графової моделі, яка відображає причинно-наслідкові зв'язки між імовірнісними змінними, що являють фактори виникнення аварії 3 одним вагоном під час його перебування на сортувальній станції. Змінна, яку подано за допомогою вищенаведеної нечіткої моделі, окремо виділена на графі. 

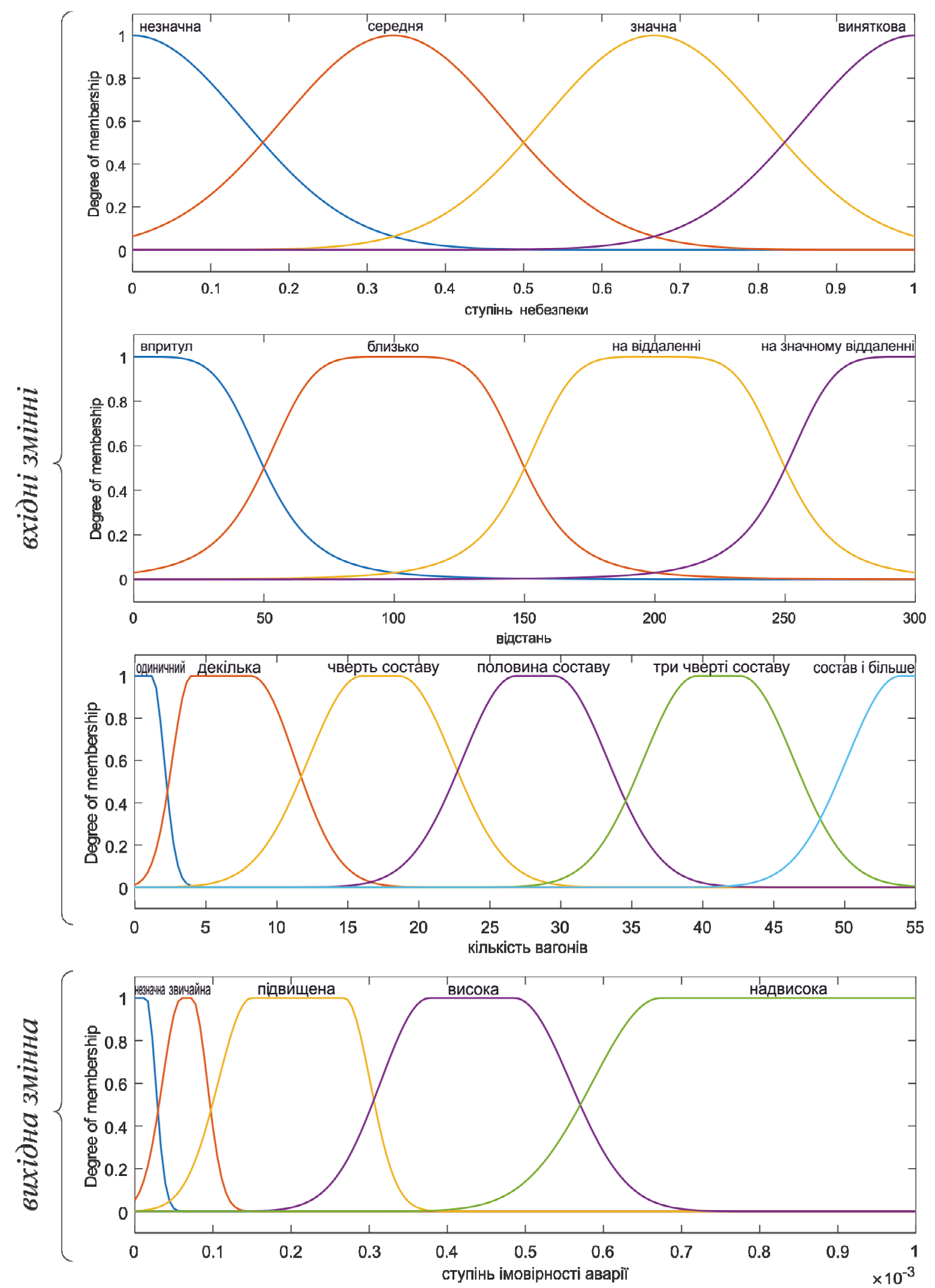

Рис. 1. Графічна інтерпретація терм-множин вхідних і вихідної лінгвістичних змінних моделі оцінювання імовірності виникнення аварії з вагоном, що перевозить НВ, на сортувальній станції 


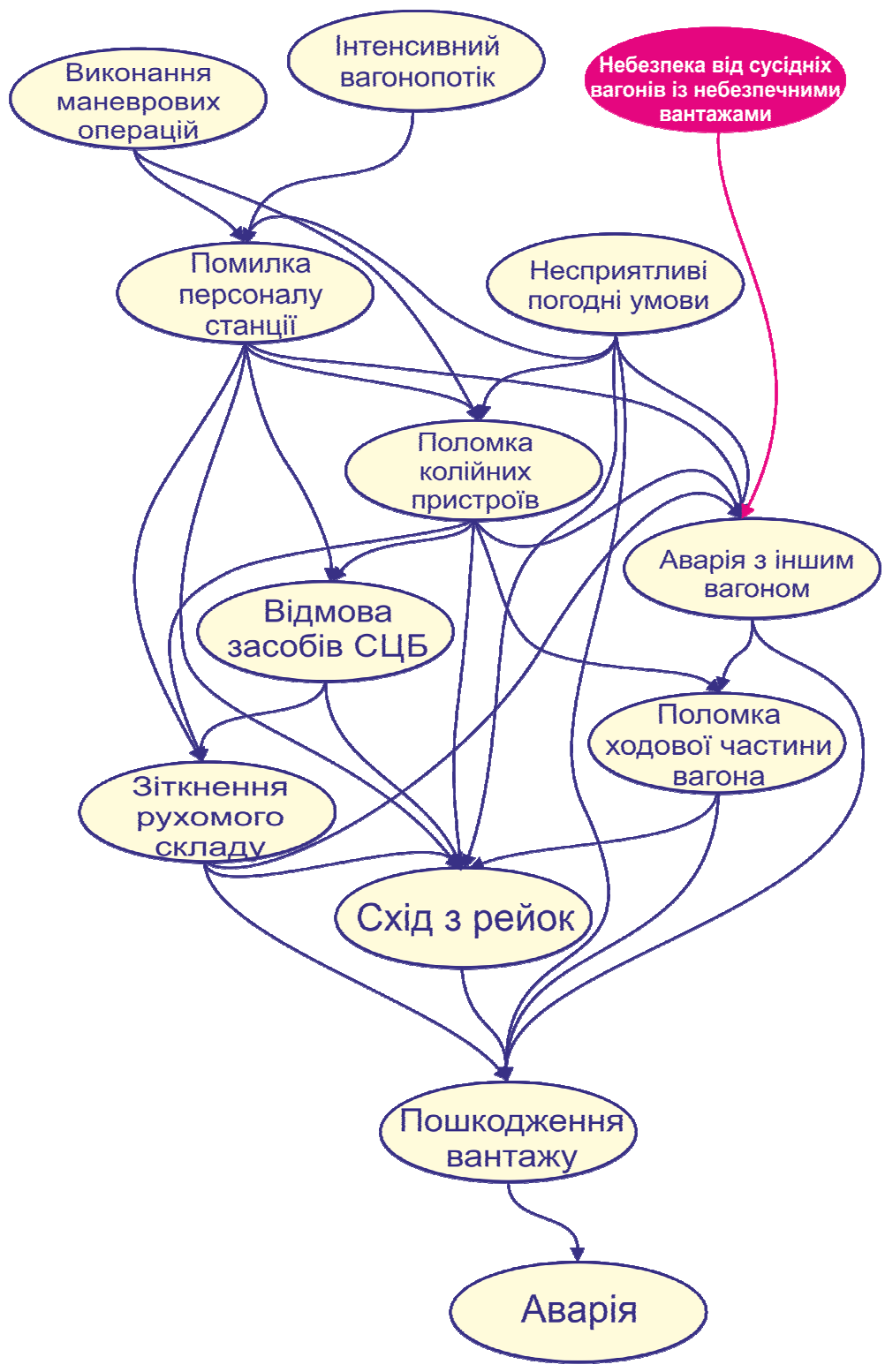

Рис. 2. Графова модель оцінки імовірності аварії з вагоном з НВ на сортувальній станції на основі математичного апарату байєсових мереж

Для того щоб ця графова структура могла функціонувати як байєсова мережа, до неї ще необхідно додати таблиці умовних імовірностей, які доцільно створити на основі статистичних даних.

\section{Висновки}

Сформовано модель оцінки імовірності виникнення аварії 3 вагоном 3 HВ під час його перебування на сортувальній станції, яка охоплює чинники, що відносяться до всіх класів небезпек. Застосування математичного апарату байєсових мереж дозволяє побудувати модель оцінки поточної імовірності аварії з вагоном з НВ шляхом урахування каузальних зв'язків між подіями, які безпосередньо або опосередковано впливають на неї, та дозволяє використовувати для iї оцінки не лише загальну статистику, а й актуальну інформацію про події та поточні стани об'єктів на станції. Застосування математичного апарату нечіткої логіки дозволило в запропонованій моделі, на відміну від існуючих моделей, також врахувати можливість виникнення аварії з вагоном з НВ, ненадійність якого оцінюється, 3 причини виникнення аварії з іншим вагоном 3 НВ. Створена модель дозволяє оцінювати ненадійність кожного вагона з НВ окремо і побудувати функцію 
ненадійності від часу, що надасть можливість детально оцінити ризик виникнення аварії на сортувальних станціях. Дана модель може бути використана при побудові сучасної автоматизованої системи управління ризиком на сортувальних станціях.

\section{Список використаних джерел}

1. Verma, M., Verter, V. Gendreau, M. A Tactical Planning Model for the Railroad Transportation of Dangerous Goods [Text] // Transportation Science. 2011. - 45(2). - P. 163-174.

2. Verma, M. A Cost and Expected Consequence Approach to Planning and Managing Railroad Transportation of Hazardous Materials [Text] // Transportation Research Part D: Transport and Environment. - 2009. - 14(5). - P. 300-308.

3. Zufferey, N., Verma, M. Tabu Search for Shipping Dangerous Goods in a Rail-Truck Network [Text] // Research in Logistics \& Production. - 2011. - № 3. P. 127-137.

4. Бутько, Т. В. Формування моделі оперативного управління процесом просування вагонів 3 небезпечними вантажами в підсистемі “технічна станція - прилегла дільниця" на базі нечіткої ситуаційної мережі [Текст] / Т. В. Бутько, А. В. Прохорченко, С. I. Музикіна

Інформаційно-керуючі системи на залізничному транспорті. - 2012. - №3. - С. 3-8.

Chekhunov D. M. Formation of model of risk assessment during the operation of wagons with hazmat at switchyards with use of mathematical apparatus of fuzzy logic and Bayesian nets. The first stage in the developing a modern automated risk management system at the switchyards is the formation of an adequate model for assessing the risk of an accident with wagons with hazmat. The model of estimation of the current probability of occurrence of an accident with a wagon with a hazmat during its stay at a sorting station with the use of the mathematical apparatus of Bayesian nets and fuzzy logic, which covers factors related to all classes of hazards and provides an opportunity to use all relevant information about events and current state of objects at the station, has been formed. In calculating the probability of an accident, the model takes into account causal relationships between the events affecting it, including the possibility of an accident with a wagon with a hazmat due to the occurrence of an accident with another wagon with a hazmat. Model allows to evaluate the unreliability of each wagon with hazmat separately and build a function of unreliability over time, which will provide an opportunity to assess in detail the risk of accidents with hazmat at the switchyards.

Keywords: wagons with hazmat, Bayesian nets, fuzzy logic, accident probability assessment.
Чехунов Д. М. Формирование модели оценки рисков на сортировочной станции при оперировании вагонами с опасными грузами с использованием математических аппаратов нечеткой логики и байесовских сетей. Разработана модель оценки вероятности возникновения аварии с вагоном с опасным грузом на сортировочной станции с использованием математического аппарата «байесовская сеть» и нечеткой логики. Модель при расчете вероятности учитывает факторы, относящиеся ко всем классам опасности, и причинно-следственные связи между событиями, влияющими на нее, дает возможность использовать информацию о событиях и текущем состоянии объектов на сортировочной станции. Модель позволяет детально оценить риск возникновения аварии с вагоном с опасным грузом и построить функцию ненадежности от времени.

Ключевые слова: вагоны с опасными грузами, байесовские сети, нечеткая логика, оценка вероятности аварии.

Надійшла 15.01.2018 p.

Chekhunov Denys Mykolayovych, post graduate, department of Management of operational work, Ukrainian State University of Railway Transport, Kharkiv, Ukraine. E-mail: uermp@ukr.net ORCID: https://orcid.org/0000-0002-1570-6351

Чехунов Денис Миколайович, аспірант, кафедра управління експлуатаційною роботою, Украӥнський державний університет залізничного транспорту, м. Харків, Україна. E-mail: uermp@ukr.net ORCID: https://orcid.org/0000-0002-1570-6351 